\title{
Challenges to social capacity building in flood-affected areas of southern Poland
}

\author{
J. Działek, W. Biernacki, and A. Bokwa \\ Jagiellonian University, Institute of Geography and Spatial Management, ul. Gronostajowa 7, 30-387 Kraków, Poland \\ Correspondence to: J. Działek (jarek.dzialek@uj.edu.pl)
}

Received: 17 December 2012 - Published in Nat. Hazards Earth Syst. Sci. Discuss.: Revised: 23 July 2013 - Accepted: 5 August 2013 - Published: 18 October 2013

\begin{abstract}
Various aspects of beliefs, behaviour and expectations of at-risk populations were analysed in four case study localities in southern Poland that were affected by flooding in 1997 and 2001. They represent localities of different sizes and are characterised by different paths of historical development. Two of them are deep-rooted communities with dense, strong family and neighbourhood ties, while the other two experienced an almost total replacement of their population due to decisions taken after World War II and still suffer from less developed social networks. Historical events also resulted in the disruption of local memories of flooding and transmission of knowledge about natural hazards. A questionnaire survey was conducted in late autumn 2006, followed by structured telephone interviews and focus group interviews in spring 2008. The results of the survey and interviews were analysed with reference to the social capacity framework and its five dimensions: knowledge, motivational, network, economic and governance capacities. Network capacities, that is resources of bonding and bridging social capital, were considered a key notion when analysing and interpreting the results. The differences in the local resources and abilities available in each of the localities to prepare a response to natural hazards were revealed. Consequently, challenges faced in the process of building and strengthening social capacity were identified as well as ways to address these challenges. It was concluded that there are general trends and tendencies that need to be considered in risk management strategies, however the different starting points of each case study community calls for different means and approaches, as well as producing somewhat different expected outcomes.
\end{abstract}

\section{Introduction}

Floods accounted for $77 \%$ of the economic losses caused by extreme weather events in Europe between 1980 and 2006 (Insurers of Europe, 2007). In Poland, floods threaten human settlements every year, with the largest recent flood disasters occurring in 1997, 2001 and 2010. The flood of 1997 affected an extremely large area and caused economic losses of about EUR 2 billion (Dubicki et al., 1999). The extraordinary scale of this event highlighted many weaknesses in natural risks (including flood risk) management in Poland, not only due to poor structural measures and inefficient forecasting, monitoring and warning systems, but also making it equally evident that pre-flood risk communication was very weak to non-existent (Kundzewicz et al., 1999; Lewandowski, 2000; Konieczny et al., 2001). The development of non-structural measures (land use planning, monitoring and warning systems, risk communication) is still relatively slow in Poland (Żelaziński, 2010) and the predicted increase in flood frequency (Parry et al., 2007) calls for further intensification of this type of protective action.

Following the 1997 events and other significant floods in 2001, the Polish Ministry of Science and Higher Education financed a research project called "Social attitudes and behaviour towards extreme phenomena" (Biernacki et al., 2009) over the period 2004-2008. Its aim was to fill the knowledge gap on the social dimensions of flood risk in southern Poland. Mountainous areas were chosen because they are particularly exposed to the flood risk, which is mainly associated with the impact of the Carpathian Mountains and the Sudetes Mountains as orographic barriers influencing precipitation patterns. The present paper revisits the flood-related results from 2004-2008 to use the 
social capacity framework developed within the CapHazNet project (Kuhlicke and Steinführer, 2010; Kuhlicke et al., 2011, 2012).

The main aim of this study was to analyse the factors and processes involved in social capacity building in selected localities, which suffered during the catastrophic floods in southern Poland in 1997 and 2001. The analysis was used to identify challenges that need to be taken into account in strengthening various dimensions of social capacities. Particular attention was paid to the effects of the different sizes and histories of the communities included in the study. The last factor was included as the different historic paths of development in various parts of Poland during the last two centuries have had a tremendous impact on their social structure today, especially their resources of social capital (Herbst and Gumkowska, 2006; Czapiński and Panek, 2011; Działek, 2011). Historical events also resulted in different patterns of flood memories, e.g. a disrupted transmission of flood histories in the Sudetes Mountains, where the population was to a large extent replaced after the Second World War in contrast to much more continuous flood history memories in deeplyrooted communities in the Carpathian Mountains.

\section{Social capacity framework}

Social capacity is the ensemble of resources available at various levels (e.g. individuals, organisations, communities) that can be used to anticipate, respond to, cope with, recover from and adapt to external stressors (e.g. a hazardous event) (Kuhlicke et al., 2011). Five types of social capacities were distinguished: knowledge, motivational, network, economic and governance capacities (Kuhlicke et al., 2012). These five dimensions cover various aspects of both individual and collective capacities when faced with natural hazards. Social capacity building is then a process aiming at recognising lacks of different types of abilities and resources, and later implementing collaborative strategies that would enhance them in order to achieve more resilient communities (Kuhlicke et al., 2011).

We addressed all types of social capacities while analysing the results of our research in southern Poland; still, network capacities were regarded as key dimension to understanding differences of other social capacities in case study localities. Developed networks of various types of relations play an important role in social capacity building in general (Kuhlicke et al., 2012) as they contribute to the building and strengthening of other capacities, especially knowledge capacities - through information exchange about risks and motivational capacities - thanks to social support and responsibility building within the community. Social networks are also considered an essential element in the participatory approach to social capacity building that focuses particularly on communities and their empowerment (in contrast to the interventionist top-down approach with more focus on public sector involvement) (Kuhlicke et al., 2012), hence leading to strengthening of local governance capacities.

Network capacities are synonymously understood in this paper as social capital resources (Coleman, 1994; Putnam et al., 1993; Putnam, 2000). Two types of social capital, bonding and bridging, seem to be pertinent when analysing social structures of case study communities (Table 1). High levels of bonding social capital, that is strong ties and personal trust among family members, friends and neighbours (Granovetter, 1974; Putnam, 2000), are typical for deeprooted, stable mountainous communities in the Carpathian Mountains (Działek, 2011). Meanwhile, in newly established communities in the Sudetes Mountains, where the German population was, as a consequence of the Second World War, expelled and replaced by Polish inhabitants from different parts of pre-war Poland (most of them expelled from territories annexed by the Soviet Union), family or neighbour ties were and still are relatively weaker than in other regions of contemporary Poland. The main outcome of this kind of a social experiment was a new society of Polish Western and Northern Territories, where bridging social capital plays the primary role (Jałowiecki and Szczepański, 2007; Zarycki, 2002).

In the context of natural hazards, both types of social capital described above are interrelated with flood memories. Bonding social capital enables the strengthening of memory about past natural disasters and the exchange of information about possible future risks and mitigation behaviour. It may have its negative externalities when more resourceful and powerful groups (e.g. local elites, privileged groups) exclude other groups such as minorities, the poor, the old, and the less educated from altruistic communities (Pelling, 1998; Kaniasty and Norris, 1995). Thus, the existence of bridging social capital (weak ties within the community) between marginalised groups and the rest of the society is crucial, as it could decrease their vulnerability to natural hazards (Cutter et al., 2003; Adger et al., 2005). Moreover, weak links may allow the transfer of knowledge about local natural hazards to e.g. new inhabitants (Berke et al., 1993; Bolin and Stanford, 1998). Abundant resources of both types of social capital (including social trust) should facilitate the taking of joint decisions (Adger, 2003) and lead to an increased involvement in participatory risk management (Dynes, 2002; Murphy, 2007; Lara et al., 2010; Schelfaut et al., 2011).

Therefore, it is interesting to uncover links between the resources of both types of social capital (and network capacities in consequence), resulting from different historical paths of case study communities, and other social capacities. Besides these historical factors, other context-specific conditions such as size of the localities and history of recent floodings (frequency and size of floods) ought to be considered in order to get a full picture of local challenges for social capacity building. 
Table 1. Characteristic features of the localities in southern Poland included in the study.

\begin{tabular}{|c|c|c|c|c|c|}
\hline Locality & $\begin{array}{l}\text { Settlement } \\
\text { type }\end{array}$ & $\begin{array}{r}\text { Population in } \\
2006 \text { (thousands) }\end{array}$ & Region & $\begin{array}{l}\text { Flood } \\
\text { experience }\end{array}$ & $\begin{array}{l}\text { Social } \\
\text { capital }^{*}\end{array}$ \\
\hline Laskowa & village & 2.7 & $\begin{array}{l}\text { the Beskid Wyspowy Moun- } \\
\text { tains, on the Łososina River }\end{array}$ & one large flash flood (1997) & $\begin{array}{l}\text { high bonding social capital, } \\
\text { medium bridging social }\end{array}$ \\
\hline \multicolumn{6}{|l|}{ capital } \\
\hline Maków Podhalański & small town & 5.7 & $\begin{array}{l}\text { the Beskid Makowski } \\
\text { Mountains, on the Skawa } \\
\text { River }\end{array}$ & one large flash flood (2001) & $\begin{array}{l}\text { high bonding social capital, } \\
\text { low bridging social capital }\end{array}$ \\
\hline Kłodzko & medium-size town & 28.1 & $\begin{array}{l}\text { Kłodzko Basin, on the Nysa } \\
\text { Kłodzka River }\end{array}$ & $\begin{array}{l}\text { one large flash flood (1997), } \\
\text { other floods in 1998, } 2006\end{array}$ & $\begin{array}{l}\text { low bonding social capital, } \\
\text { medium bridging social }\end{array}$ \\
\hline \multicolumn{6}{|l|}{ capital } \\
\hline Opole & large town & 127.6 & $\begin{array}{l}\text { Silesian Lowland, on the } \\
\text { Oder/Odra River }\end{array}$ & one large slow flood (1997) & $\begin{array}{l}\text { low bonding social capital, } \\
\text { high bridging social capital }\end{array}$ \\
\hline
\end{tabular}

Notes: * source: Działek (2011).

\section{Study area, data and methods}

The analyses presented below are based on research carried out in four localities in southern Poland: Laskowa, Maków Podhalański, Kłodzko and Opole (Table 1). The localities were chosen as case studies as they differ significantly in the number of inhabitants, flood experience in the period 1985-2005 and in the character of resources of social capital which result from their history. Laskowa and Maków Podhalański are located in the Carpathian Mountains, where the communities have developed continuously despite many dramatic historical events, while in Kłodzko and Opole the local communities were almost completely re-established after the Second World War due to post-war migration and political change. Social capital resources (Działek, 2011) were measured at the powiat (county) level on the basis of seven indicators describing density of non-governmental organisations, membership in arts, sports and other hobby groups, and membership in religious and church organisations. A principal component analysis was later conducted to identify two dimensions of social capital - bonding and bridging.

The four case study localities were selected out of nine where social attitudes to flooding were studied within the project "Social attitudes and behaviour towards extreme phenomena" (Biernacki et al., 2009). The remaining five localities are: Bielsko-Biała, Jordanów, Ostrowiec Świętokrzyski, Grabownica and Polanica-Zdrój (Fig. 1). The selection was made using information available including historical accounts, central and local government reports, and mass media reports. Because of the individual nature of the places and the floods, the conclusions of this study cannot be directly extrapolated to the national level.

The methods used included:

- questionnaire survey: questionnaires were distributed in late autumn 2006 via local schools and 1036 were sent back from the four localities;

- in-depth interviews: 45 telephone interviews were conducted in spring 2008 with randomly chosen
Table 2. Demographic characteristics of the respondents from the four case study localities.

\begin{tabular}{ll}
\hline $\begin{array}{l}\text { Demographic } \\
\text { characteristics }\end{array}$ & $\begin{array}{l}\text { Share of respondents } \\
\text { in per cent }(N=1036)\end{array}$ \\
\hline Age: & 33.9 \\
$18-35$ & 59.0 \\
$36-50$ & 6.2 \\
$>50$ & 1.0 \\
no answer & \\
\hline Gender: & 23.5 \\
male & 75.4 \\
female & 1.2 \\
no answer & \\
\hline Education: & 29.7 \\
primary and vocational & 46.7 \\
secondary & 21.8 \\
higher & 1.7 \\
no answer & \\
\hline
\end{tabular}

Source: authors' own elaboration.

inhabitants of three of the four case study localities: Laskowa, Kłodzko, Opole (interviews were not conducted in Maków Podhalański for technical reasons);

- 2 focus group interviews with local leaders and risk managers in spring 2008: representatives of all nine localities included in the project participated.

The questionnaires were composed in such a way as to get an insight into the following aspects of people's attitudes to floods: their awareness of past events, their perception of future risks, and actions undertaken individually or collectively in order to prepare for the occurrence of this risk. The main demographic characteristics of the respondents from the four localities are shown in Table 2.

Cramér's $V$ index was used to measure the association between respondents' location and the variables describing various aspects of social capacities. It is the most commonly 

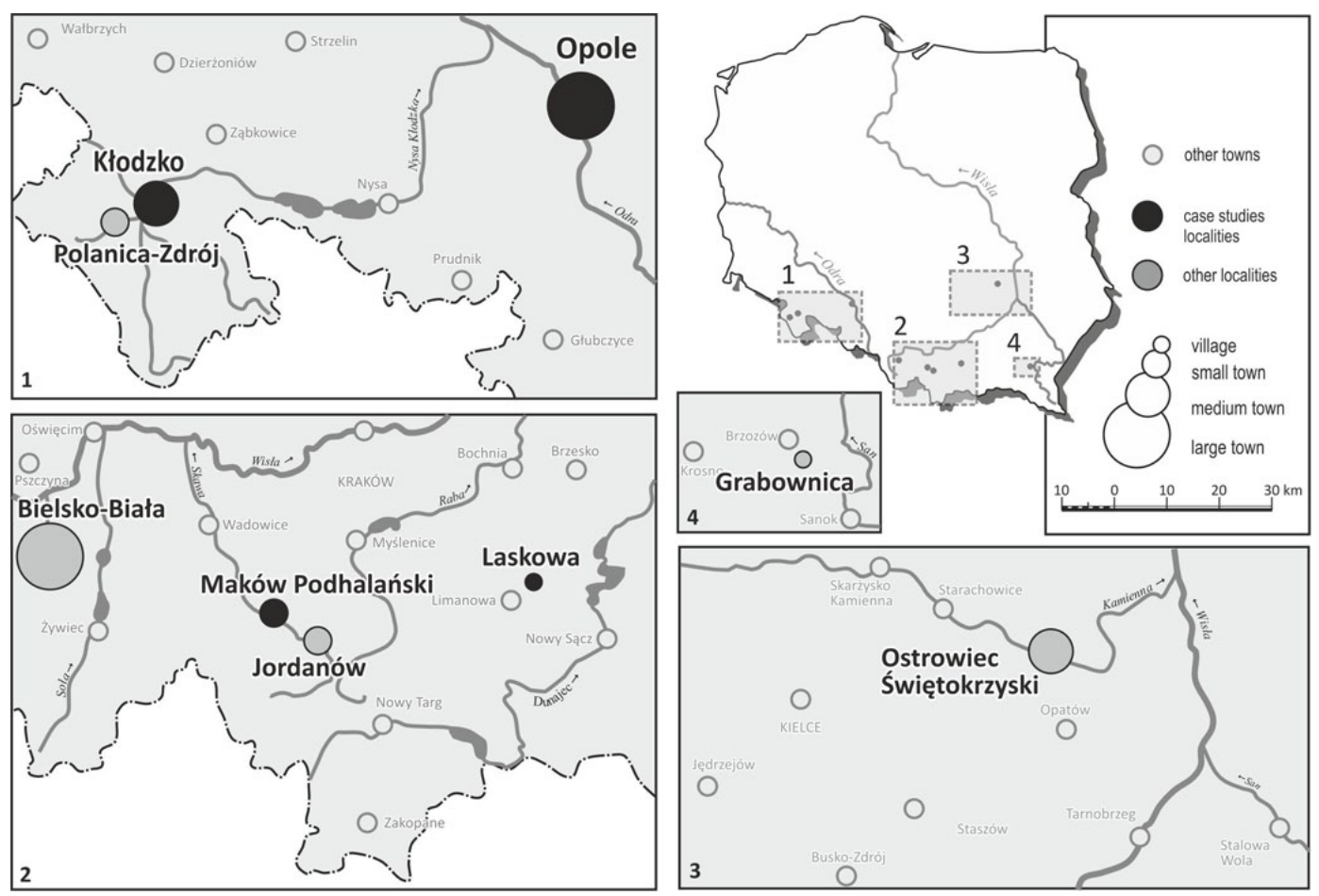

Fig. 1. Localities in southern Poland included in the study. Source: spatial data from Biernacki et al. (2009).

used variation of the contingency coefficient, which shows association for nominal variables and yields values between 0 and +1 . Although this measure lacks clear interpretation, it is assumed that the more it departs from zero, the higher the association is between the variables. Values of Cramér's $V$ between 0.25 and 0.5 are considered statistically moderately significant, yet, in the social sciences they would be evaluated as meaningful (Bishop et al., 2007; Blaikie, 2003).

\section{Results}

This section presents beliefs and behaviour studied in the four selected localities in southern Poland that were assigned to particular types of social capacity, distinguished according to Kuhlicke et al. (2012).

\subsection{Knowledge capacities}

Knowledge capacities include both expert and lay knowledge about natural hazards. Knowledge about possible risks may come from various sources of information preferred by the inhabitants (e.g. Kreibich et al., 2009). In southern Poland, personal observation and local mass media dominate. However, personal contact is the prevailing means of communication in smaller settlements, while mass media are preferred by those living in larger towns (Table 3).

The results also suggest that historically formed social networks are important in local knowledge-gathering and exchange. Maków Podhalański is a Carpathian town with strong social bonds developed by many generations of people living there, while in Opole, a large city in western Poland, those bonds are much weaker due to the migrations after the Second World War and the gradual establishment of a community consisting of populations coming from various regions.

Flood memories and stories (Kempe, 2007) may also play an important role in building knowledge capacities in these localities. Building and enhancing local knowledge about past events (Konieczny et al., 2001; Bradford et al., 2012; McEwen and Jones, 2012) should be an important part of social capacity building. This goal should be achieved through strategies tailored to the historical backgrounds of each site. While the inhabitants of Laskowa and Maków Podhalański can share stories relating to earlier flood experiences (e.g. which areas were flooded and which remain free of buildings) such as those about the major flood in 1934, the collective memory in Kłodzko and Opole dates back only to the post-war period and does not include that much information about the earlier major flood in 1938 which destroyed that area. Recent floods are often of a large spatial extent and the representatives of emergency services are aware of the potential benefit of using social memory in building knowledge capacities, as shown in the following opinion:

RESPONDENT. In contrast, the experience of the flood in 1997 is still in the peoples' minds. It keeps coming back. It is 
Table 3. Share of the respondents (\%) declaring having obtained information about natural hazards from particular sources of information.

\begin{tabular}{lrrrr}
\hline \multirow{2}{*}{ Source of information } & \multicolumn{4}{c}{ Locality } \\
\cline { 2 - 5 } & Laskowa & Maków Podhalański & Kłodzko & Opole \\
& $N=289$ & $N=103$ & $N=166$ & $N=471$ \\
\hline Personal observation & 55.0 & 68.9 & 54.8 & 40.8 \\
Interpersonal communication & 28.7 & 35.9 & 26.5 & 17.6 \\
School & 6.6 & 6.8 & 10.8 & 1.9 \\
Local mass media & 65.7 & 44.7 & 68.7 & 85.6 \\
Leaflets & 3.8 & 8.7 & 5.4 & 6.4 \\
Meetings, training courses & 4.2 & 3.9 & 1.8 & 2.1 \\
Other sources & 1.0 & 2.9 & 13.3 & 4.5 \\
\hline
\end{tabular}

Notes: $N$ - number of respondents; more than one answer could be chosen. Source: authors' own elaboration.

a collective experience. And it did not affect a small group, but tens of thousands of people in general. ${ }^{1}$

The understanding of flood mechanisms is of great importance for knowledge and later for motivational capacities, i.e. dealing with natural hazards and undertaking action to mitigate the impact of flooding. For example, Botzen et al. (2009) quantified hazard-related knowledge by asking respondents about the causes of a flood. They found that individuals with little knowledge of the causes of flooding have lower perceptions of flood risks. This outcome is supported by Raaijmakers et al. (2008) who state that the provision of flood-risk information to the public usually increases their awareness or perception. Interviews in the study area showed that people are sometimes trying to find an irrational explanation for flood events which are believed to be exceptional and unpredictable. They often resort to folk proverbs or magical thinking, like in the following statements:

RESPONDENT. We have a Holy Mary column and many people believe that if you disturb it the town will be plagued with catastrophes. This happened many years ago when the town was ravaged with cholera. About a month before the flood, they started digging around the market square and many inhabitants still think this was the cause. ${ }^{2}$

RESPONDENT. [Floods had come] every 4 years: in 1997, in 2001 and as 2005 approached [people started wondering if] something could happen. Everybody thinks in his own way, analyses, subconsciously knows that this danger may actually occur. (focus group interview)

Global warming is sometimes also blamed, but for the occurrence of the flood itself rather than as a factor intensifying the occurrence and scale of extreme events.

Knowledge about flood risk and its causes can be evaluated as moderate, and it is associated with perceived low probability of that risk in comparison with other potential non-natural "everyday" threats such as criminality, car

\footnotetext{
${ }^{1}$ Focus group interview, representative of the fire department from Opole, 4 April 2008.

${ }^{2}$ Focus group interview, local activist from Wola Przemykowska, 12 April 2008.
}

accidents or loss of a job. The underestimation of natural hazards, typical not only for Poland (Fischer, 1991; Działek, 2013), results in weakening knowledge and motivational capacities - large flooding is then perceived as a "radical surprise" (Kuhlicke, 2010).

\subsection{Motivational capacities}

The motivation to prepare for and cope with a flood risk is strongly linked to the understanding of the causes of flood losses and the conviction that these losses can be avoided or diminished thanks to action to mitigate their impact.

In southern Poland, most respondents are convinced that poor protective infrastructure is the main factor responsible for high flood losses (Table 4). Indeed, only a small minority agrees that the location of the buildings, too close to the river and within flood zones, could have been the cause. That conclusion is further supported with the following opinions:

RESPONDENT. Every time there is a media report, a question is posed as to whether you feel safe. And where some measures, some new hydrotechnical structures, have been erected or a section of a river secured, people there say that it's got better. But there are places where nothing has been done and these people will always say that they don't feel safe. ${ }^{3}$

RESPONDENT. The authorities, you have to know, have given a candlestick and a pack of matches, these flood packages, this is ridiculous. What are needed are new or repaired levees! ${ }^{4}$

However, an analysis of the occurrence of floods showed more responses indicating poor infrastructure as the cause in sites that had experienced a single large flood, than in sites of more flooding episodes (cf. Bradford et al., 2012). This result may be explained by a diminishing confidence in structural measures by communities affected by frequent floods.

\footnotetext{
${ }^{3}$ Focus group interview, representative of the fire department from Opole, 4 April 2008.

${ }^{4}$ Telephone interview, inhabitant of Kłodzko, 19 March 2008.
} 
Table 4. Share of the respondents (\%) identifying different main causes of flood losses

\begin{tabular}{lrrrr}
\hline \multirow{2}{*}{ Cause of flood losses } & \multicolumn{4}{c}{ Locality } \\
\cline { 2 - 5 } & Laskowa & Maków Podhalański & Kłodzko & Opole \\
& $N=105$ & $N=96$ & $N=153$ & $N=357$ \\
\hline Force of huge flood wave & 30.5 & 25.0 & 19.0 & 15.7 \\
Poor protective infrastructure & 55.2 & 74.0 & 65.4 & 73.1 \\
Wrong location of the buildings & 14.3 & 1.0 & 15.7 & 11.2 \\
\hline
\end{tabular}

Notes: $\mathrm{N}-$ number of respondents; $\chi^{2}($ d.f. $=6)=27.27, p<0.05$, Cramér's $V=0.138, p<0.05$. Source: authors' own elaboration.

The respondents usually underestimated the role of the force of a huge flood wave as the main reason for the losses. The smaller the settlement, the higher the belief in the power of natural forces that cannot be controlled. This is exemplified by the village of Laskowa, which has the highest proportion of responses indicating both the destructive force of the flood wave and that not much can be done to decrease the losses (Table 5). This is also a pattern of how rural communities, far more attached to nature and with much more lay knowledge about natural processes, contrast with urban communities which tend to place much more faith in technology (White, 1974). Consequently, trust in public structural measures against flood hazard is negatively correlated with individual preparedness (mitigation behaviour, insurance purchase, information seeking) (Grothmann and Reuswig, 2006; Hung, 2009; Terpstra, 2011).

Members of traditional communities may also represent a psychological type with an external locus of control, and perceive natural disasters as divine retribution or ill fate. At the other end of the spectrum are individuals with an internal locus of control, who tend to take personal responsibility for such events and believe that damage and harm can be prevented by active measures (Bell et al., 2005; Lin et al., 2008; McClure et al., 1999). Externalist attitude results in a prevailing feeling of helplessness when potential possible actions are confronted with the dimension of the disaster already experienced, like in the following opinion:

RESPONDENT. [Floods] would appear in no time at all, five minutes and the element would come out of the blue, impossible to predict. 5

This fatalist approach, related also to the nature of flash floods in the mountains, results in weaker motivational capacities.

\subsection{Network capacities}

Two types of network relationships were analysed in the context of the degree of preparedness against natural hazards: cooperation between individual persons and cooperation between inhabitants and their local authorities (Table 6). The

\footnotetext{
${ }^{5}$ Focus group interview, local activist from Śleszowice, 12 April 2008.
}

results obtained show clear differences between the small Carpathian localities of Laskowa and Maków Podhalański, with high-bonding social capital, and the larger localities of Kłodzko and Opole, located in south-western Poland, with less developed strong ties. In the smaller localities, joint actions are much more frequent than in the larger ones, both due to a more positive attitude to direct contacts and due to much stronger social bonds.

These results suggest that different regional values and norms towards collective behaviour developed during long historical processes may result in the strengthening or weakening of local response to flood risk. Bonding social capital clearly plays the most important role and its higher level translates into a willingness to undertake preventive actions, not only collectively, but also individually, as proven in responses to another question. This effect may be due to a more efficient information flow in a dense local network, crossgenerational transmission of memories of past floods, their extent, damage, methods of prevention that worked during past floods, etc. Strong community ties also translate into a level of confidence in local authorities and emergency services, often leading to more frequent contacts with these bodies.

It could, therefore, be expected that it would be easier to introduce a participatory approach to flood risk management in areas with stronger bonding social capital due to greater involvement of the local community. In this context the resources of bridging social capital are less relevant, but they could be far more important in risk communication and education strategies, where the lay knowledge of established communities on natural hazards could be used to strengthen the resilience of new community members (McEwen and Jones, 2012).

\subsection{Economic capacities}

Economic capacities are the financial resources available, and those necessary to cope with the hazard. When an event occurs, the funds provided by insurance companies might be an important element in the economic resources available. Therefore, the purchasing of an insurance policy is an element of economic capacity building. The results from southern Poland are in accordance with those presented for 
Table 5. Share of the respondents (\%) agreeing with different evaluations of the possibility of a decrease in flood losses.

\begin{tabular}{lrrrr}
\hline \multirow{2}{*}{ Evaluation } & \multicolumn{4}{c}{ Locality } \\
\cline { 2 - 5 } & Laskowa & Maków Podhalański & Kłodzko & Opole \\
& $N=289$ & $N=103$ & $N=166$ & $N=471$ \\
\hline Definitely possible & 22.0 & 41.6 & 43.6 & 46.2 \\
Partially possible & 51.4 & 47.5 & 45.5 & 48.7 \\
Not much can be done & 26.6 & 10.9 & 10.9 & 5.0 \\
\hline
\end{tabular}

Notes: $N$ - number of respondents; $\chi^{2}$ (d.f. $\left.=9\right)=52.77, p<0.05$, Cramér's $V=0.151, p<0.05$. Source: authors' own elaboration.

Table 6. Share of respondents (\%) declaring the undertaking of various protective actions within the local community.

\begin{tabular}{lcrrr}
\hline \multirow{2}{*}{ Locality } & $\begin{array}{l}\text { Undertaking joint protective } \\
\text { actions together with } \\
\text { other inhabitants }\end{array}$ & $\begin{array}{l}\text { Asking local authorities, } \\
\text { individually or as a group, } \\
\text { to undertake protective actions }\end{array}$ \\
\cline { 2 - 5 } of yes & 18.5 & 65 & 37.9 & $N$ \\
\hline Laskowa & 37.7 & 69 & 39.7 & 66 \\
Maków Podhalański & 20.5 & 88 & 13.8 & 68 \\
Kłodzko & 4.8 & 273 & 6.3 & 87 \\
Opole & & & 272 \\
\hline
\end{tabular}

Notes: $N$ - number of respondents; these two questions were answered only by those respondents who had earlier answered that their household was in a flood risk area. Undertaking joint protective actions: $\chi^{2}$ (d.f. $=3$ ) $=55.81, p<0.05$, Cramér's $V=0.336, p<0.05$. Asking local authorities: $\chi^{2}$ (d.f. $\left.=3\right)=69.91, p<0.05$, Cramér's $V=0.377, p<0.05$. Source: authors' own elaboration.

western Europe (Paklina, 2003), which showed a generally low level of insurability (Table 7). Rural areas in Poland are exceptional and more people buy policies in comparison to people in large cities, as some types of insurance are obligatory for agricultural production. The general reluctance of the population to insure themselves is in many cases the result of the human perception of risk that neglects events with very low probabilities of occurrence (Slovic et al., 2005), or of the expectation that governmental and private aid will be obtained when disaster happens (Raschky and Weck-Hannemann, 2007). Economically vulnerable groups may also find that other daily expenses are more important than spending on insurance against flood that they do not believe will happen again soon as shown in the following opinion:

RESPONDENT. If you haven't been flooded for 10 years then why spend on protection when you can pay for the daily needs, which are no less important. ${ }^{6}$

The respondents in the survey of southern Poland who declared that their houses were located in flood risk areas were also asked about their individual investments in technical facilities to protect their buildings (Table 8). A clear difference can again be seen between the Carpathian localities and the localities in western Poland. In Laskowa and Maków Podhalański about a third of the respondents declared undertaking such an activity, while in Kłodzko and Opole it is much rarer. The more intense activity of the respondents from rural areas and small towns is connected with home ownership and their feelings of attachment and direct responsibility (Bradford et al., 2012). In the larger towns, where most people live in blocks of flats, individual activities are often not even possible.

The previously mentioned historical differences in the level of local identity and attachment to the place are added to that. Indeed, decades after the Second World War, the population of what is known as the Western and Northern Territories, i.e. the territories gained at the expense of Germany, has retained a sense of temporariness and is slow to take root. This pattern is corroborated by the response to a question asking whether people living in a risk area would consider moving to a safer location. In general, only a limited number of respondents would consider this option as being possible, while more than half would never take up this kind of decision. One-third admitted that it would be a good solution but they had no financial resources to implement it. In Kłodzko and Opole a much higher share of the population (one-quarter to one-third) than in Maków or Laskowa (one in ten to fifteen) wants to change their place of residence because of the danger of flooding.

\footnotetext{
${ }^{6}$ Focus group interview, journalist of regional newspaper from Kraków1, 2 April 2008.
} 
Table 7. Share of the respondents $(\%)$ declaring that they have purchased insurance policies.

\begin{tabular}{lrrrr}
\hline \multirow{2}{*}{ Purchase of insurance } & \multicolumn{4}{c}{ Locality } \\
\cline { 2 - 5 } & Laskowa & Maków Podhalański & Kłodzko & Opole \\
& $N=288$ & $N=100$ & $N=163$ & $N=467$ \\
\hline No & 40.6 & 51.0 & 61.3 & 60.2 \\
Only that which is obligatory & 39.2 & 22.0 & 16.0 & 18.0 \\
Only an optional one & 17.0 & 20.0 & 20.2 & 19.7 \\
Obligatory and optional ones & 3.1 & 7.0 & 2.5 & 2.1 \\
\hline
\end{tabular}

Explanations: $N$ - number of respondents. $\chi^{2}($ d.f. $=9)=61.66, p<0.05$, Cramér's $V=0.142, p<0.05$. Source authors' own elaboration.

Table 8. Share of the respondents (\%) from endangered areas declaring having undertaken individual investments in technical facilities to protect particular buildings against floods.

\begin{tabular}{lrrrr}
\hline \multirow{2}{*}{ Undertaking action to mitigate risk } & \multicolumn{4}{c}{ Locality } \\
\cline { 2 - 5 } & $\begin{array}{r}\text { Laskowa } \\
N=66\end{array}$ & Maków Podhalański & Kłodzko & Opole \\
& 33.3 & $3=69$ & $N=88$ & $N=272$ \\
\hline Yes & 66.7 & 63.8 & 81.8 & 94.5 \\
No & & 36.2 & 18.2 \\
\hline
\end{tabular}

Notes: $N$ - number of respondents; this question was answered only by those respondents who had earlier answered e that their household is in flood risk area. $\chi^{2}$ (d.f. $=3$ ) $=59.04, p<0.05$, Cramér's $V=0.345, p<0.05$. Source: authors' own elaboration.

\subsection{Governance capacities}

Governance capacities relate to various risk governance settings and relations among actors involved in risk management. Risk governance in Poland represents a more paternalist and interventionist approach as well as low levels of devolution of responsibility to the population with respect to flood risks. Risk communication and education is still underdeveloped and little is done to encourage people to increase their resilience.

The study for southern Poland did not address issues of risk governance directly, but some indirect results might be useful for the general evaluation of these capacities. Regardless of the size of the locality or its experience of flooding, a large majority of the respondents expect, first of all, local, regional and national authorities to take responsibility for protective actions (70-80\% on average) (Table 9). In smaller localities though, a few more respondents were inclined to shift the responsibility to themselves than in towns. The focus interviews confirmed that people expect the authorities, above all, to organise and finance the construction of flood defences, while providing e.g. rescue kits during the flood is perceived as useless and inadequate to mitigate flood damage. This general attitude may be a consequence of communist times, when state provided support in many areas of life. Although more than two decades have passed, this paternalist approach is still accepted and even expected, and there is a general belief that flood protection is a state affair.

\subsection{Challenges to social capacity building}

The study found that differences in the preferred channels for information acquisition and especially in the willingness to participate in meetings on local threats and ways to address them, were linked to the size of localities and their history. There is a strong contrast between rural and other small and deeply rooted communities with strong ties and larger towns where networks are more limited, partly due to historical processes. The less strong the neighbourhood ties the more frequently individual observations and experiences need to be complemented by other sources of knowledge (e.g. media reports). Also knowledge about the local environment (including causes, potential course and options of controlling floods) is rather moderate and this deficit is sometimes made up in a process of constructing knowledge by linking to misunderstood effects of global warming or through reference to supernatural effects.

The continued difficulty in interpreting and predicting floods in combination with their often enormous force causes the emergence of a strong desire to "become separated" from floods using technical means, a desire which is much stronger in towns than in the countryside. An improvement in structural protective measures is what most respondents, especially in towns, see as their main option in reducing flood damage. Also the belief that the role of technical means is most important, combined with weak community bonds, limits willingness to work together within the community or to seek the direct support of local government and other bodies. 
Table 9. Share of the respondents (\%) expressing an opinion as to who should be mainly responsible for actions aimed at protecting particular buildings against floods.

\begin{tabular}{lrrrr}
\hline \multirow{2}{*}{ Responsible person or institution } & \multicolumn{4}{c}{ Locality } \\
\cline { 2 - 5 } & Laskowa & Maków Podhalański & Kłodzko & Opole \\
& $N=100$ & $N=87$ & $N=157$ & $N=344$ \\
\hline Me and my family & 28.0 & 20.7 & 11.5 & 13.4 \\
Me together with my neighbours & 4.0 & 8.0 & 7.6 & 4.7 \\
Local authorities & 46.0 & 60.9 & 66.9 & 61.3 \\
Regional and national authorities & 22.0 & 10.3 & 14.0 & 20.6 \\
\hline
\end{tabular}

Notes: $N$ - number of respondents. $\chi^{2}$ (d.f. $\left.=9\right)=27.79, p<0.05$, Cramér's $V=0.116, p<0.05$. Source: authors' own elaboration.

The belief that one can be completely "separated" from a flood also leads to a very low level of readiness to invest financially in securing property, especially among urban respondents who strongly believe in technical measures.

The differences in the perception of and potential for the prevention of floods in each of the localities explain a high proportion of responses which indicate that it is the responsibility of various levels of government to provide flood protection infrastructure. Urban communities have the strongest belief in the effectiveness of physical protection and the lowest declared individual activities intended to protect private assets. In western Poland this admitted low level of spending on individual protection is additionally diminished by a sense of temporariness felt in these territories and by a lower level of rootedness compared to other parts of Poland.

These results point to a strong two-way dependence between knowledge and motivational capacities. A lack of adequate knowledge influences willingness to deal with a risk, while a lack of motivation results in a weaker need to look for knowledge about this hazard. Added to that is the financial potential of individuals and households, which also justifies an option to invest in home protection or a policy covering against the perceived risk. Another challenge is the use and enhancement of network capacities that may vary between regions of the country and community sizes. The trust in structural measures and the shift of responsibility towards public institutions constitute a challenge to governance capacities in terms of the strengthening of community participation in risk governance.

\section{Conclusions}

Flood risk management in Poland is in its early stages. The Flood Directive is being introduced by the Krajowy Zarząd Gospodarki Wodnej (KZGW, National Water Management Authority) which is now implementing a nation-wide IT system to protect the country against hydrological hazards. Hazard and risk maps are currently being prepared as part of this project. Its costs are estimated to be about EUR 75 million and it will be operable by 2015 and used by crisis management units and emergency services (Raport z wykonania wstępnej oceny ryzyka powodziowego, 2011). These kinds of large investments are needed, but they should be followed by steps taken closer to the local community. While national agencies declare in their information materials that a change is needed in the way of thinking about floods, they keep operating in accordance with old habits that are typical of an interventionist approach.

The results presented in this paper may be used as an indication and starting point for actions intended to empower both communities and local authorities as is proposed in the Hyogo Framework for Action 2005-2015 (2007). The process of social capacity building should have a local focus, because, as has already been shown, each of the sites included in the study has its specific local character and, sometimes, different expectations. Naturally, there are also internal differences within each community where individuals and households have different circumstances and expectations. Nevertheless, the results illustrate that the four case study localities clearly differ in terms of observed lack of or weaknesses in different capacities. Means that could be used to improve the situation, as well as the outcomes expected should address these differences (cf. O'Sullivan et al., 2012).

Based on the conclusions of the study certain recommendations can be put forward to improve social capacity building in Poland.

- The low level of interest in flood-related topics in the period between catastrophic floods (which can be long) requires new initiatives to strengthen social memory about the local nature of floods (cf. Bradford et al., 2012). This should take into account the disruption of knowledge transfer in the Western and Northern Territories as a result of the replacement of the population after the Second World War;

- Institutions responsible for risk management should aim to pass on in a communicative way the information they posses about local risks (e.g. risk maps), their mechanisms and the potential for damage mitigation, etc. (cf. O'Sullivan et al., 2012). They should increase 
the involvement of the local communities (e.g. through workshops) in the exchange of knowledge, in dialogue, and through their more active participation in local risk management. Educational and information activities should use multiple channels, but their design needs to be different for rural and urban environments due to their different preferred channels of communication;

- Institutions responsible for risk management should considerably increase their efforts to strengthen resilience of local communities through their engagement in risk management and to encourage undertaking individual and collective flood mitigation measures (cf. Schelfaut et al., 2011). Their communication and education strategies should include reinforcing public confidence that individual and collective private protective behaviour is as equally as important as public structural measures;

- Migration processes, including not just extreme cases such as a complete replacement of populations, but also significant inward or outward migrations, contribute to a weakening of social ties (bonding social capital), which translates into a lowering of both individual and collective flood-protection activity (cf. Blyth, 2001; Lara et al., 2010; Bradford et al., 2012). This means that in areas where the level of social capital is low, there is a growing need to build and strengthen its resources.

Results of the survey and interviews have shown strengths and weaknesses within five dimensions of social capacities in case study localities. Local abilities and resources to cope with natural hazards are a consequence of a large number of factors, some dating back significantly in history (boundary changes, mass displacement of population), others very recent (large floodings, new migrants in large cities and in suburbanising rural areas). Still, we concluded that the historical processes that led to different population structures in case study communities (especially their resources of bonding and bridging social capital), are one of the most significant factors in explaining the level of development of all types of social capacities. Additionally, the size of the localities and, to a lesser extent, recent flooding characteristics play a role in weakening or strengthening the implications of historical factors. Social capital, or network capacities, proved to be interdependent with knowledge, motivational, economic and governance capacities. Local strategies aiming at overcoming challenges in social capacity building should, in our opinion, take into account and address differences in resources of social capital when undertaking efforts to introduce community-based approaches to risk management. Local cultural institutions (such as libraries, local museums) and community centres would be places where both social capital strengthening (cf. Murzyn-Kupisz and Działek, 2013) and risk communication and education activities could be undertaken at the same time to address all types of social capacities. Finally, besides these general observations and recommendations resulting from our studies in four localities in southern Poland, we need to keep in mind that both research and practice should always consider local contextual conditions when assessing local social capacities in the context of natural hazards. We consider these more universal trends and tendencies from quantitative analyses as background for more in-depth, qualitative research within and with local communities.

Acknowledgements. This paper benefited from a research grant which was a part of a national project "Extreme meteorological and hydrological events. Assessment of the events and forecasting their effects on the human environment" (PBZ-KBN-86/P04/2003), financed by the Polish Ministry of Science and Higher Education. The authors would like to thank our colleagues Bolesław Domański, Tomasz Padło and Karol Janas for their cooperation during the project. We also would like to express our cordial thanks for Annett Steinführer, Maria Hagemeier-Klose and two anonymous referees for their remarks and suggestions, which have been invaluable in improving this manuscript.

Edited by: A. Steinführer

Reviewed by: M. Hagemeier-Klose and

two anonymous referees

\section{References}

Adger, W. N.: Social Capital, Collective Action, and Adaptation to Climate Change, Econ. Geogr., 79, 387-404, 2003.

Adger, W. N., Hughes, T. P., Folke, C., Carpenter, S. R., and Rockström, J.: Social-Ecological Resilience to Coastal Disasters, Science, 309, 1036-1039, 2005.

Bell, P. A., Greene, T., Fisher, J., and Baum, A. S.: Environmental Psychology, Orlando, Harcourt College Publishers, 2005.

Berke, P., Kartez, J., and Wenger, D.: Recovery after disaster: achieving sustainable development, mitigation and equity, Disasters, 17, 93-109, 1993.

Biernacki, W., Bokwa, A., Działek, J., and Padło T.: Społeczności lokalne wobec zagrożeń przyrodniczych i klęsk żywiołowych, Instytut Geografii i Gospodarki Przestrzennej UJ, Kraków, 2009.

Bishop, Y. M. M., Fienberg, S. E., and Holland, P. W.: Discrete multivariate analysis, Springer, New York, 2007.

Blaikie, N. W. H.: Analysing quantitative data: from description to explanation, Sage Publications, London, Thousand Oaks, CA, 2003.

Blyth, K., Baltas, E., Benedini, M., and Givone, P.: Risk of inundation - planning and response interactive user system, Telematics Application Programme, 2001.

Bolin, R. and Stanford, L.: The Northridge earthquake: communitybased approaches to unmet recovery needs, Disasters, 22, 21-38, 1998.

Botzen, W. J. W, Aerts, J. C. J. H., and van den Bergh, J. C. J. M.: Dependence of flood risk perceptions on socioeconomic and objective risk factors, Water Resour. Res., 45, doi:10.1029/2009WR007743, 2009. 
Bradford, R. A., O’Sullivan, J. J., van der Craats, I. M., Krywkow, J., Rotko, P., Aaltonen, J., Bonaiuto, M., De Dominicis, S., Waylen, K., and Schelfaut, K.: Risk perception - issues for flood management in Europe, Nat. Hazards Earth Syst. Sci., 12, 2299-2309, doi:10.5194/nhess-12-2299-2012, 2012.

Coleman, J. S.: Foundations of social theory, First Harvard University Press, Cambridge, 1994.

Cutter, S. L., Boruff, B. J., and Shirley, W. L.: Social Vulnerability to Environmental Hazards, Soc. Sci. Quart., 84, 242-261, 2003.

Czapiński, J. and Panek, T. (Eds): Social Diagnosis: 2011 Objective and Subjective Quality of Life in Poland - full report, Contemporary Economics, Quarterly of University of Finance and Management in Warsaw, 5, 1-366, 2011.

Dubicki, A., Słota, H., and Zieliński, J. (Eds): Monografia powodzi lipiec 1997, Dorzecze Odry Instytut Meteorologii i Gospodarki Wodnej, Warszawa, 1999.

Dynes, R. R.: The importance of social capital in disaster response, University of Delaware, Disaster Research Centre, Preliminary Paper \#327, 2002.

Działek, J.: Kapitał społeczny jako czynnik rozwoju gospodarczego w skali regionalnej i lokalnej w Polsce, Wydawnictwo Uniwersytetu Jagiellońskiego, Kraków, 2011.

Działek, J.: Perception of Natural Hazards and Disasters, in: Encyclopedia of Natural Hazards, edited by: Bobrowsky, P. T., Springer, 756-759, 2013.

Fischer, W. F., Granger Morgan, M., Fischhoff, B., Nair, I., and Lave, L. B.: What Risks Are People Concerned About?, Risk Anal., 11, 303-314, 1991.

Granovetter, M. S.: Getting a job: a study of contacts and careers, Harvard University Press, Cambridge, 1974.

Grothmann, T. and Reusswig, F.: People at risk of flooding: Why some residents take precautionary action while others do not, Nat. Hazards, 38, 101-120, 2006.

Herbst, J. and Gumkowska, M.: Wolontariat, filantropia i $1 \%$, Raport z badań 2006, Stowarzyszenie Klon/Jawor, Warszawa, 2007.

Hung, H. C.: The attitude towards flood insurance purchase when respondents' preferences are uncertain: A fuzzy approach, J. Risk Res., 12, 239-258, 2009.

Hyogo Framework for Action 2005-2015: Building the resilience of nations and communities to disasters. Extract from the final report of the World Conference on Disaster Reduction (A/CONF.206/6), Geneva: United Nations Office for Disaster Risk Reduction (UNISDR), 2007.

Insurers of Europe (CEA): Reducing the Social and Economic Impact of Climate Change and Natural Catastrophes: Insurance Solutions and Public-Private Partnerships, Brussels, 2007.

Jałowiecki, B. and Szczepański, M. S.: Dziedzictwo polskich regionów, in: Jedna Polska. Dawne i nowe zróżnicowania społeczne, Wydawnictwo WAM, edited by: Kojder, A., Polska Akademia Nauk, Kraków, 59-87, 2007.

Kaniasty, K. and Norris, F. H.: In search of altruistic community: patterns of social support mobilization following Hurricane Hugo, Am. J. Commun. Psychol., 23, 447-477, 1995.

Kempe, M.: "Mind the Next Flood!” Memories of Natural Disasters in Northern Germany from the Sixteenth Century to the Present, Mediev. Hist. J., 10, 327-354, 2007.

Konieczny, R., Madej, P., and Siudak, M.: Local Flood Hazard Reduction Plans in Poland - Problems and Perspectives, in: Coping with flash floods, edited by: Gruntfest, E. and Handmer, J., Kluver Academic Publishers, 2001.

Kreibich, H., Thieken, A. H., Grunenberg, H., Ullrich, K., and Sommer, T.: Extent, perception and mitigation of damage due to high groundwater levels in the city of Dresden, Germany, Nat. Hazards Earth Syst. Sci., 9, 1247-1258, doi:10.5194/nhess-9-12472009, 2009.

Kuhlicke, C.: The dynamics of vulnerability: some preliminary thoughts about the occurrence of "radical surprises" and a case study on the 2002 flood (Germany), Nat Hazards, 55, 671-688, 2010.

Kuhlicke, C. and Steinführer, A.: Social Capacity Building for Natural Hazards. A Conceptual Frame, CapHaz-Net WP1 Report, Leipzig, Helmholtz Centre for Environmental Research - UFZ, available at: http://caphaz-net.org/outcomes-results/ CapHaz-Net_WP1_Social-Capacity-Building.pdf (last access: 17 April 2013), 2010.

Kuhlicke, C., Steinführer, A., Begg, C., Bianchizza, C., Bründl, M., Buchecker, M., De Marchi, B., Di Masso Tarditti, M., Hoppner, C., Komac, B., Lemkowe, L., Luther, J., McCarthy, S., Pellizzoni, L., Renn, O., Scolobig, A., Supramaniam, M., Tapsell, S., Wachinger, G., Walker, G., Whittle, R., Zorn, M., and Faulkner H.: Perspectives on social capacity building for natural hazards: outlining an emerging field of research and practice in Europe, Environ. Sci. Policy, 14, 804-814, 2011.

Kuhlicke, C., Steinführer, A., Begg, C., and Luther, L.: Toward More Resilient Societies in the Field of Natural Hazards: CapHaz-Net's Lessons Learnt, CapHaz-Net WP10 Final Report, Helmholtz Centre for Environmental Research UFZ: Leipzig \& Johann Heinrich von Thünen Institute: Braunschweig, available at: http://caphaz-net.org/outcomes-results/ CapHazNet_Del\%2010.3_final.pdf (last access 18 April 2013), 2012.

Kundzewicz, Z. W., Szamalek, K., and Kowalczak, P.: The Great Flood of 1997 in Poland, Hydrol. Sci. J., 44, 855-870, 1999.

Lara, A., Saurí, D., Ribas, A., and Pavón, D.: Social perceptions of floods and flood management in a Mediterranean area (Costa Brava, Spain), Nat. Hazards Earth Syst. Sci., 10, 2081-2091, doi:10.5194/nhess-10-2081-2010, 2010.

Lewandowski, A.: Flood management in Poland, in: Flood Issues in Contemporary Water Management, edited by: Marsalek, J., Watt, W. E., Zeman, E., and Sieker, F., NATO Science Series, 71, 2000.

Lin, S., Shaw, D. and Ho, M.-C.: Why are flood and landslide victims less willing to take mitigation measures than the public?, Nat. Hazards, 44, 305-314, 2008.

McClure, J., Walkey, F., and Allen, M.: When earthquake damage is seen as preventable: Attributions, locus of control and attitudes to risk, Appl. Psychol. Int. Rev., 48, 239-256, 1999.

McEwen, L. J. and Jones, O.: Building local/lay flood knowledges into community flood resilience planning after the July 2007 floods, Gloucestershire, UK, Hydrol. Res., 43, 675-688, 2012.

Murphy, B. L.: Locating social capital in resilient community-level emergency management, Nat. Hazards, 41, 297-315, 2007.

Murzyn-Kupisz, M. and Działek, J.: Cultural heritage in building and enhancing social capital, J. Cult. Heritage Manage. Sust. Develop., 3, 35-54, 2013.

O’Sullivan, J. J., Bradford, R. A., Bonaiuto, M., De Dominicis, S., Rotko, P., Aaltonen, J., Waylen, K., and Langan, S. J.: Enhancing flood resilience through improved risk communications, Nat. 
Hazards Earth Syst. Sci., 12, 2271-2282, doi:10.5194/nhess-122271-2012, 2012

Paklina, N.: Flood insurance, OECD, Paris, 2003.

Parry, M. L., Canziani, O. F., Palutikof, J. P., and Co-authors: Technical Summary, in: Climate Change 2007: Impacts, Adaptation and Vulnerability, Contribution of Working Group II to the Fourth Assessment Report of the Intergovernmental Panel on Climate Change, edited by: Parry, M. L., Canziani, O. F., Palutikof, J. P., van der Linden, P. J., and Hanson, C. E., Cambridge University Press, Cambridge, UK, 23-78, 2007.

Pelling M.: Participation, social capital and vulnerability to urban flooding in Guyana, J. Int. Develop., 10, 469-486, 1998.

Putnam, R. D.: Bowling alone: the collapse and revival of American community, Simon \& Schuster, New York, 2000.

Putnam, R. D., Leonardi, R., and Nanetti R.: Making democracy work: civic traditions in modern Italy, Princeton University Press, Princeton, N. J., 1993.

Raaijmakers, R., Krywkow, J., and van der Veen, A.: Flood risk perceptions and spatial multicriteria analysis: an exploratory research for hazard mitigation, Nat. Hazards, 46, 307-322, 2008.
Raport z wykonania wstępnej oceny ryzyka powodziowego, Warszawa: IMiGW, KZGW, 2011.

Raschky, P. A. and Weck-Hannemann, H.: Charity hazard. A real hazard to natural disaster insurance?, Environ. Hazards, 7, 321329, 2007.

Schelfaut, K., Pannemans, B., van der Craats, I., Krywkow, J., Mysiak, J. and Cools, J.: Bringing flood resilience into practice: the FREEMAN project, Environ. Sci. Policy, 14, 825-833, 2011

Slovic, P., Peters, E., Finucane, M. L., and Macgregor, D. G.: Affect, risk, and decision making, Health Psychol., 24, 35-40, 2005.

Terpstra, T.: Emotions, trust and perceived risk: Affective and cognitive routes to flood preparedness behavior, Risk Anal., 31, 1658-1675, 2011.

White, G. F. (Ed.): Natural Hazards: Local, National, Global, New York: Oxford University Press, 1974.

Zarycki, T.: Region jako kontekst zachowań politycznych, Wydawnictwo Scholar, Warszawa, 2002.

Żelaziński, J.: Nauczmy się żyć powodziami. Let's learn to live with flooding, Infos, Biuro Analiz Sejmowych, 2, 1-4, 2011. 